\title{
Effect of Organic Manures on Growth, Yield and Quality of Assam Lemon [Citrus limon (L.) Burm.]
}

\author{
Rosangpuii Pachuau $^{1}$, Barun Singh ${ }^{1}$, Jes Lalnunpuia ${ }^{2}$ and Lalthamawii ${ }^{3}$ \\ ${ }^{1}$ College of Horticulture and Forestry, Central Agricultural University, \\ Pasighat-791102, Arunachal Pradesh, India \\ ${ }^{2}$ College of Forestry, Thrissur, Vellanikara-680656, Kerala, India \\ ${ }^{3}$ School of Agricultural Sciences and Rural Development, Medziphema-797106, \\ Nagaland, India
}

*Corresponding author

\section{A B S T R A C T}

\section{Keywords}

organic, manures, Assam Lemon, yield, quality.

\section{Article Info}

Accepted:

14 August 2019 Available Online: 10 September 2019
The investigation was carried out on two years old trees at the Citrus Fruit Block, Department of Fruit Science, College of Horticulture and Forestry, Pasighat, Arunachal Pradesh during the year 2018 to evaluate the effect of organic manures on the overall character of Assam Lemon. The experiment was laid out in Randomized Block Design (RBD) with 12 treatments and 3 replications viz. $\mathrm{T}_{1}-$ Control, $\mathrm{T}_{2}-\mathrm{RDF}: \mathrm{N}: \mathrm{P}: \mathrm{K}$ (100:100:100 g/plant/year), $\mathrm{T}_{3}$ - FYM (20kg/tree), $\mathrm{T}_{4}-$ Vermicompost $(10 \mathrm{~kg} /$ tree $), \mathrm{T}_{5}$ Neem Cake (2kg/tree), T 6 - Mustard Oil Cake (2kg/tree), $T_{7}-$ FYM (10 kg/tree) + Neem Cake (1kg/tree), $\mathrm{T}_{8}-$ FYM (10kg/tree) + Mustard Oil Cake $(1 \mathrm{~kg} /$ tree $), \mathrm{T}_{9}-$ Vermicompost $(5 \mathrm{~kg} /$ tree $)+$ Neem Cake $(1 \mathrm{~kg} /$ tree $), \mathrm{T}_{10}-$ Vermicompost $(5 \mathrm{~kg} /$ tree $)+$ Mustard Oil Cake $(1 \mathrm{~kg} /$ tree $), \mathrm{T}_{11}-\mathrm{FYM}(10 \mathrm{~kg} /$ tree $)+$ Mustard Oil Cake $(1 \mathrm{~kg} /$ tree $)+$ Neem Cake $(1 \mathrm{~kg} / \mathrm{tree})$ and $\mathrm{T}_{12}-$ Vermicompost $(5 \mathrm{~kg} /$ tree $)+$ Mustard Oil Cake $(1 \mathrm{~kg} /$ tree $)+$ Neem Cake (1 kg/tree). Maximum number of fruits/plant (85.66), fruit set $(30.02 \%)$ and yield/plant $(9.60 \mathrm{~kg})$, juice content $\left(47.46 \mathrm{ml} /\right.$ fruit), TSS $\left(5.78{ }^{\circ} \mathrm{B}\right)$, total sugar $(6.19 \%)$, reducing sugar $(3.62 \%)$, ascorbic acid $(52.63 \mathrm{mg} / 100 \mathrm{~g})$, available nitrogen $(430.52 \mathrm{~kg} / \mathrm{ha})$, available phosphorus $(57.30 \mathrm{~kg} / \mathrm{ha})$, available potassium $(306.13 \mathrm{~kg} / \mathrm{ha})$, organic carbon $(2.62 \%)$, total nitrogen $(2.35 \%)$, total phosphorus $(0.16 \%)$ and total potassium $(1.66 \%)$ was recorded by treatment $\mathrm{T}_{10}$ - Vermicompost $(5 \mathrm{~kg} /$ tree $)+$ Mustard Oil Cake $(1 \mathrm{~kg} / \mathrm{tree})$. However, non-significant effect was found in vegetative growth parameters. Thus, application of Vermicompost $(5 \mathrm{~kg} /$ tree $)+$ Mustard Oil Cake $(1 \mathrm{~kg} /$ tree $)$ before flowering to get the best crop with maximum yield and quality.

\section{Introduction}

Assam lemon, a native dwarf cultivar of the state of Assam is suitable for high density planting and locally known as Kazi Nemu (Barua and Bharadwaj, 2017). The fruit is comparatively larger in size than the regular lemon and hence, the juice content is also much more. Nutrition is an important input that determines the soil health and production as a whole. The application of nutrients to both young and maturing trees determines the 
vegetative development of citrus trees (Morgan, 2009). The soil health is depleting at a fast rate due to the extensive use of inorganic fertilizers and its toxic residual effects and thus the concept of organic citrus production is gaining interest from the farmers and researchers alike. According to Heitkamp et al., (2009), chemical fertilizers can boost plant growth, yield and quality whereas with application of organic manures, there is addition of organic matter to the soil and thus the effect is doubled. Approaches have been made for shifting to organic cultivation at a larger scale. The farmers of North Eastern India have been practising conventional farming for generations with almost null consumption of chemical fertilizers, which is a pedestal in comparison to the consumption in other parts of the country. Sikkim has been declared a full-fledged organic state and other North Eastern states are soon to attain this status in the near future. However, very little research work has been done in the organic aspects of fruit crops cultivation. Thus standardization of the organic nutritional requirement is necessary for sustainable fruit production. Recognizing the need for organic fruit production, with locally available organic manures, the present study was conducted to study the effect of organic manures on vegetative growth, yield and fruit quality of Assam lemon.

\section{Materials and Methods}

The study was carried out in Randomized Block Design on two years old Assam lemon plants with locally available organic manures viz. Farm Yard Manure (FYM), Vermicompost (VC), Mustard Oil Cake (MOC) and Neem Cake (NC) singly and in combination during the year 2018 at the Citrus Fruit Block, Department of Fruit Science, College of Horticulture and Forestry, Central Agricultural University, Pasighat, East Siang District, Arunachal Pradesh. The recommended dose of fertilizer (RDF) for Assam Lemon at 100:100:100 g NPK/plant/year was also applied as on the treatments. The treatments were $\mathrm{T}_{1}$ - Control, $\mathrm{T}_{2-}$ RDF of N:P:K (100:100:100 g/plant/year), $\mathrm{T}_{3^{-}}$FYM (20kg/tree), $\mathrm{T}_{4^{-}}$Vermicompost (10kg/tree), $\mathrm{T}_{5^{-}}$Neem Cake ( $2 \mathrm{~kg} /$ tree), $\mathrm{T}_{6^{-}}$ Mustard Oil Cake (2kg/tree), T $7^{-}$FYM (10 $\mathrm{kg} /$ tree $)+$ Neem Cake $(1 \mathrm{~kg} /$ tree $), \mathrm{T}_{8^{-}}$FYM $(10 \mathrm{~kg} /$ tree $)+$ Neem Cake $(1 \mathrm{~kg} /$ tree $), \mathrm{T}_{9^{-}}$ Vermicompost $(5 \mathrm{~kg} /$ tree $)+$ Neem Cake (1kg/tree), $\mathrm{T}_{10^{-}}$Vermicompost $(5 \mathrm{~kg} /$ tree $)+$ Mustard Oil Cake (1kg/tree), $\mathrm{T}_{10^{-}}$ Vermicompost $(5 \mathrm{~kg} /$ tree $)+$ Mustard Oil Cake (1kg/tree), T $11^{-}$FYM $(10 \mathrm{~kg} /$ tree $)+$ Mustard Oil Cake $(1 \mathrm{~kg} /$ tree $)+$ Neem Cake $(1 \mathrm{~kg} /$ tree $)$ and $\mathrm{T}_{12^{-}}$Vermicompost $(5 \mathrm{~kg} /$ tree $)+$ Mustard Oil Cake $(1 \mathrm{~kg} /$ tree $)+$ Neem Cake $(1 \mathrm{~kg} /$ tree $)$. The organic manures were incorporated to the plants in full dose and the inorganic fertilizers in half dose before flowering (FebruaryMarch). The remaining half of the inorganic fertilizers dose was applied in June for boosting the growth of the developing fruits. Uniform inter-cultural operations were done on all the plants. The soil $\mathrm{pH}$ was estimated by potentiometric method using a $\mathrm{pH}$ meter in a soil-water suspension in the ratio of $1: 2.5$, electrical conductivity (EC) by conductometric method using a digital EC meter in a soil-water suspension in the ratio of $1: 2.5$, organic carbon by wet digestion method (Walkley and Black, 1934), available nitrogen by alkaline $\mathrm{KMnO}_{4}$ method (Subbiah and Asija, 1956), available $\mathrm{P}_{2} \mathrm{O}_{5}$ by Bray's method for acid soil (Bray and Kurtz, 1945) and available $\mathrm{K}_{2} \mathrm{O}$ by Ammonium Acetate method (Hanway and Heidal, 1952).

The total nitrogen, total phosphorus and total potassium of leaves were estimated by Kjeldahl method, vandomolybdate yellow colour method and flame photometric method respectively. The initial nutrient status of the soil of the experimental plot is: $\mathrm{pH}-6.20$, electrical conductivity (EC) - $0.78 \mathrm{dSm}^{-1}$, 
available nitrogen - $275.96 \mathrm{~kg} / \mathrm{ha}$, available $\mathrm{P}_{2} \mathrm{O}_{5}-23.52 \mathrm{~kg} / \mathrm{ha}$, available $\mathrm{K}_{2} \mathrm{O}-240 \mathrm{~kg} / \mathrm{ha}$ and organic carbon- $2.0 \%$.

Plant growth characteristics were observed and tagged for subsequent record. Ten fruits from each treatment were randomly selected to record the data on physico-chemical characters. The total soluble solids content was determined with a hand-held refractometer $\left(0-32^{\circ} \mathrm{Brix}\right)$, the titratable acidity by the method as suggested in AOAC (2002), total sugar content by Anthrone method (Hodge and Hofreiter, 1962), reducing sugar content by Spectrophotometric method (Somogyi, 1952) and ascorbic acid content according to titration method described by Ranganna (1986). Significance and nonsignificance of the variance due to different treatments were determined by calculating the respective ' $F$ ' values according to the method described by Gomez and Gomez (2010). The statistical analysis was done using WASP 2.0.

\section{Results and Discussion}

\section{Vegetative Growth Parameters}

The application of organic manures through different sources of sole or combined application did not show significant influence on the plant vegetative growth characters. This may be because the investigation was done for only one year. Significant result on vegetative growth can be expected if the investigation is continuously carried out for 2-3 years. Nevertheless, maximum mean increment in plant height $(26.57 \mathrm{~cm}, 14.94 \%)$, canopy spread in North-South direction $(55.8 \mathrm{~cm}$, $48.00 \%$ ) and canopy spread in East-West direction $(46.30 \mathrm{~cm}, 34.80 \%)$ were observed in treatment $\mathrm{T}_{10}$ (Vermicompost @ $5 \mathrm{~kg}+$ Mustard Oil Cake @ 1kg). The maximum increment in the stem girth was recorded in the treatment $T_{2}$ which received the RDF through the chemical fertilizers.

\section{Yield and yield attributing parameters}

Maximum fruit set (30.02\%), highest number of fruits (85.66) and maximum fruit yield per plant $(9.60 \mathrm{~kg})$ were recorded in the treatment $\mathrm{T}_{10}$. Minimum fruit set $(22.10 \%)$ was observed in treatment $\mathrm{T}_{5}$ which was at par with treatments $T_{3}$ and $T_{8}$. The lowest was observed in $\mathrm{T}_{5}$ (34.00), which exhibited parity with the control plants (37.33). The lowest yield was recorded in $\mathrm{T}_{5}(3.06 \mathrm{~kg})$ which showed parity with control plants $(4.02 \mathrm{~kg})$.

\section{Fruit Physical Parameters}

The maximum fruit length $(8.59 \mathrm{~cm})$ and fruit diameter $(5.04 \mathrm{~cm})$ was recorded in treatment $\mathrm{T}_{5}(8.59 \mathrm{~cm})$ while the minimum fruit length $(7.86 \mathrm{~cm})$ and fruit diameter $(4.48 \mathrm{~cm})$ was recorded in control $T_{1}$. Maximum fresh fruit weight was recorded in $\mathrm{T}_{9}$ (Vermicompost @ $5 \mathrm{~kg}+$ Neem cake@1 @g) and highest juice content in $\mathrm{T}_{10}$ (Vermicompost @ $5 \mathrm{~kg}+$ Mustard Oil cake @ 1kg).

\section{Fruit Quality Parameters}

The imposition of organic manures caused significant variation on the quality parameters of the fruits. In case of the quality parameters, the treatment $\mathrm{T}_{10}$ (Vermicompost@ $@ 5 \mathrm{~kg}+$ Mustard Oil Cake@1kg) gave the maximum TSS $\left(5.78^{\circ} \mathrm{B}\right)$ and Ascorbic acid content $(52.63 \%)$ with total sugar content $(6.19 \%)$, reducing sugar $(3.62 \%)$ and non-reducing sugar $(2.57 \%)$ which was equivalent to the RDF.

\section{Soil and Leaf Nutrient Status}

Analysis of the data showed that the majority of the soil and leaf parameters gave significantly relevant results to the effect of the application of organic manures. However, there was no significant effect on the $\mathrm{pH}$ and electrical conductivity. The rest of the soil and 
leaf characteristics viz. available nitrogen, available phosphorus, available potassium, organic carbon content of the soil and total nitrogen, total phosphorus and total potassium of the leaves recorded highest in $\mathrm{T}_{10}$ (Vermicompost @ 5kg + Mustard Oil Cake @ $1 \mathrm{~kg})$.

\section{Plant Growth Parameters}

In this investigation, it was observed that there was increase in the plant growth characters due to the effect of the application of organic manures. Nitrogen being an important component of protein and chlorophyll, plays a crucial role in stimulating the uptake and assimilation of other nutrients and thus directs the growth of the plant as a whole. The amended application of vermicompost and mustard oil cake gave the best result, this could be due to the incorporation of large quantity of nitrogen along with balanced supply of phosphorus and potassium. Increase in the plant growth parameters under the application of organic manures have also been reported by Sangeeta et al., (2017) in pomegranate, Ghosh et al., (2014) in sweet orange and Uddin et al., (2014) in strawberry. Ghosh et al., (2014) in particular, reported the maximum vegetative growth due to the application of vermicompost among different organic manures.

\section{Yield and Yield Attributing Parameters}

Nitrogen encourages the emergence of new flushes. Assam lemon is a current shoot bearing crop and with the application of nitrogen, there is an increase in the development of new shoots and thus the increase in the canopy. The increase in the vegetative growth facilitates increase of areas for fruit setting resulting in higher yield and more number of fruits. The yield of the organically treated plants was significantly higher when compared to that of the RDF treated plants through inorganic fertilizers. Subsequently, the benefit of integration of the organic manures is clearly evident when compared to the sole application. The yield was much higher in those treatments which have combination of the manures. This is because of the addition of more nutrients into the soil. The use of organic manures has double effect due to the addition of organic matter into the soil and hence has a long term positive effect on the soil health (Heitkamp et al., 2009). Similar reports of increase in the yield under the influence of organic manures have been made by Perungkotturselvi and Koilraj (2015) in acid lime, Sangeeta et al., (2017) in pomegranate and Ghosh et al., (2014) in sweet orange.

\section{Fruit Quality Parameters}

It was found that the treatments with vermicompost as a sole or in combination in combination with other organic sources gave better quality in both biochemical and physical attributes of the fruit. Vermicompost contains essential nutrients in accessible forms which escalates the plant growth by easily supplying them when needed.

There was enhancement in the physicochemical properties of soil, enzymatic activity and microbial population due to the imposition of vermicompost. The plants which produced higher number of fruits had smaller sized fruits in comparison to those plants which produced lesser number of fruits.

The improvement in biochemical quality of fruits may be due to the proper supply of nutrients and induction of hormones, which enhances cell division and elongation, larger size and weight of fruits, better root development, better water uptake and deposition of nutrients. It may also be due to the increased $\mathrm{N}$ addition and the catalytic activity of several enzymes. 
Table.1Effect of organic manures on the growth parameters of Assam lemon

\begin{tabular}{|c|c|c|c|c|c|c|c|c|c|c|c|c|c|c|c|c|}
\hline \multirow[t]{3}{*}{ Treatments } & \multirow{2}{*}{\multicolumn{4}{|c|}{ Plant height (cm) }} & \multirow{2}{*}{\multicolumn{4}{|c|}{ Tree Girth $(\mathrm{cm})$}} & \multicolumn{8}{|c|}{ Canopy Spread (cm) } \\
\hline & & & & & & & & & \multicolumn{4}{|c|}{$\mathrm{N}-\mathrm{S}$ direction } & \multicolumn{4}{|c|}{ E-W direction } \\
\hline & Initial & Final & $\begin{array}{l}\text { Increase } \\
(\mathrm{cm})\end{array}$ & $\begin{array}{c}\text { Increase } \\
\%\end{array}$ & Initial & Final & $\begin{array}{c}\text { Increase } \\
(\mathrm{cm})\end{array}$ & $\begin{array}{c}\text { Increase } \\
\%\end{array}$ & Initial & Final & $\begin{array}{l}\text { Increase } \\
(\mathrm{cm})\end{array}$ & $\begin{array}{c}\text { Increase } \\
\%\end{array}$ & Initial & Final & $\begin{array}{c}\text { Increase } \\
(\mathrm{cm})\end{array}$ & $\begin{array}{c}\text { Increase } \\
\%\end{array}$ \\
\hline $\mathrm{T}_{1}$ : Control & 151.33 & 167.80 & 16.47 & 10.98 & 11.16 & 12.91 & 1.75 & 15.7 & 146.8 & 180.5 & 33.70 & 24 & 141.30 & 167.20 & 25.90 & 21.20 \\
\hline $\begin{array}{l}T_{2} \quad: \quad \text { RDF } \\
\text { (N:P:K- } \\
\text { 100:100:100) }\end{array}$ & 141.50 & 158.60 & 17.10 & 12.60 & 10.16 & 12.47 & 2.31 & 22.50 & 139.3 & 186.6 & 47.3 & 34 & 136.50 & 170.50 & 34.00 & 24.60 \\
\hline $\begin{array}{l}T_{3} \quad: \quad F Y M \\
(20 \mathrm{~kg} / \text { tree })\end{array}$ & 166.66 & 190.20 & 23.54 & 13.81 & 11.50 & 13.2 & 1.70 & 15.28 & 162.6 & 198.8 & 36.2 & 22.8 & 155.50 & 201.50 & 46.00 & 32.40 \\
\hline $\begin{array}{l}T_{4} \quad: \\
(10 \mathrm{~kg} / \text { tree })\end{array}$ & 162.33 & 170.20 & 7.87 & 4.98 & 11.00 & 12.41 & 1.41 & 13.07 & 159.3 & 177.8 & 18.50 & 11.4 & 150.00 & 165.50 & 15.50 & 10.20 \\
\hline $\begin{array}{ll}\mathrm{T}_{5} \quad: & \mathrm{NC} \\
(2 \mathrm{~kg} / \text { tree }) & \end{array}$ & 152.00 & 168.30 & 16.30 & 10.60 & 11.83 & 12.76 & 0.93 & 15.06 & 158.6 & 184.6 & 26.00 & 16.06 & 153.80 & 184.20 & 30.40 & 21.60 \\
\hline $\begin{array}{l}\mathrm{T}_{6}: \text { MOC } \\
(2 \mathrm{~kg} / \text { tree })\end{array}$ & 163.66 & 178.60 & 14.94 & 8.93 & 12.00 & 14.06 & 2.06 & 17.43 & 174.1 & 195.8 & 21.7 & 12.1 & 155.60 & 179.50 & 23.90 & 15.40 \\
\hline $\begin{array}{lr}T_{7} \quad: & \text { FYM } \\
(10 k g) & + \\
\text { NC(1 kg) } & \end{array}$ & 160.66 & 179.20 & 18.54 & 11.06 & 13.83 & 14.86 & 1.03 & 7.28 & 160 & 225 & 65 & 43.8 & 160.50 & 205.20 & 44.70 & 27.50 \\
\hline $\begin{array}{ll}T_{8}: & \text { FYM } \\
(10 \mathrm{~kg})+ & \text { MOC } \\
(1 \mathrm{~kg}) & \\
\end{array}$ & 178.00 & 191.30 & 13.30 & 7.62 & 12.50 & 14.78 & 2.28 & 18.35 & 179.6 & 217.8 & 38.2 & 23 & 160.80 & 206.30 & 45.50 & 30.90 \\
\hline $\begin{array}{l}T_{9} \quad: \quad V C \\
(5 \mathrm{~kg})+\mathrm{NC}(1 \mathrm{~kg})\end{array}$ & 173.50 & 179.60 & 6.10 & 3.52 & 11.16 & 12.67 & 1.51 & 13.00 & 149.1 & 201 & 51.9 & 35.7 & 136.00 & 171.00 & 35.00 & 25.73 \\
\hline $\begin{array}{l}T_{10}: V C(5 \mathrm{~kg})+ \\
\operatorname{MOC}(1 \mathrm{~kg})\end{array}$ & 178.83 & 205.40 & 26.57 & 14.94 & 12.83 & 13.88 & 1.05 & 7.90 & 122.5 & 178.3 & 55.8 & 48 & 136.00 & 182.30 & 46.30 & 34.80 \\
\hline $\begin{array}{lr}T_{11:} & \text { FYM } \\
(10 \mathrm{~kg})+ & \text { NC } \\
(1 \mathrm{~kg})+ & \text { MOC } \\
(1 \mathrm{~kg}) & \end{array}$ & 156.33 & 177.30 & 20.97 & 13.93 & 14 & 17.01 & 3.01 & 21.82 & 194.1 & 218.5 & 24.4 & 12.7 & 186.60 & 227.30 & 40.70 & 21.60 \\
\hline $\begin{array}{l}T_{12}: \operatorname{VC}(5 \mathrm{~kg})+ \\
\mathrm{NC}(1 \mathrm{~kg})+ \\
\operatorname{MOC}(1 \mathrm{~kg})\end{array}$ & 186.50 & 196.00 & 9.50 & 5.15 & 13.83 & 15.55 & 1.72 & 12.35 & 165.1 & 186.8 & 21.7 & 13.1 & 173.50 & 199.50 & 26.00 & 14.50 \\
\hline CD@5\% & NS* & NS* & NS* & NS* & NS* & NS* & NS* & NS* & NS* & NS* & NS* & NS* & NS* & NS* & NS* & NS* \\
\hline
\end{tabular}

*NS= non-significant, $\mathrm{CD}=$ critical difference, $\mathrm{CV}=$ co-efficient of variance 
Table.2 Effect of organic manures on yield and yield attributing parameters

\begin{tabular}{|c|c|c|c|}
\hline Treatments & Fruit set (\%) & $\begin{array}{c}\text { Number of fruits } \\
\text { per plant }\end{array}$ & $\begin{array}{c}\text { Yield } \\
\text { (kg/plant) }\end{array}$ \\
\hline$T_{1}$ : Control & 22.55 & 37.33 & 4.02 \\
\hline$T_{2}:$ RDF (N:P:K- 100:100:100) & 25.73 & 55.00 & 6.61 \\
\hline$T_{3}:$ FYM $(20 \mathrm{~kg} /$ tree $)$ & 23.93 & 41.33 & 4.78 \\
\hline$T_{4}:$ VC $(10 \mathrm{~kg} /$ tree $)$ & 24.31 & 47.00 & 5.04 \\
\hline$T_{5}: \mathrm{NC}(2 \mathrm{~kg} /$ tree $)$ & 22.10 & 34.00 & 3.06 \\
\hline$T_{6}:$ MOC (2kg/tree) & 26.90 & 62.00 & 6.55 \\
\hline$T_{7}:$ FYM $(10 \mathrm{~kg})+\mathrm{NC}(1 \mathrm{~kg})$ & 26.94 & 67.33 & 7.58 \\
\hline$T_{8}:$ FYM $(10 \mathrm{~kg})+\mathrm{MOC}(1 \mathrm{~kg})$ & 24.67 & 48.66 & 4.61 \\
\hline$T_{9}:$ VC (5kg)+NC(1kg) & 25.81 & 57.33 & 6.94 \\
\hline$T_{10}: \operatorname{VC}(5 \mathrm{~kg})+\operatorname{MOC}(1 \mathrm{~kg})$ & 30.02 & 85.66 & 9.60 \\
\hline$T_{11:}$ FYM $(10 \mathrm{~kg})+$ NC $(1 \mathrm{~kg})+$ MOC $(1 \mathrm{~kg})$ & 27.43 & 67.00 & 7.42 \\
\hline$T_{12}: \operatorname{VC}(5 \mathrm{~kg})+\mathrm{NC}(1 \mathrm{~kg})+\mathrm{MOC}(1 \mathrm{~kg})$ & 28.73 & 69.66 & 6.71 \\
\hline CD@5\% & 3.43 & 11.95 & 1.70 \\
\hline CV & 10.86 & 12.59 & 16.5 \\
\hline
\end{tabular}

$\mathrm{CD}=$ critical difference, $\mathrm{CV}=$ co-efficient of variance

Table.3 Effect of organic manures on the fruit physical parameters of Assam lemon

\begin{tabular}{|c|c|c|c|c|}
\hline Treatments & $\begin{array}{l}\text { Fruit length } \\
\text { (cm) }\end{array}$ & $\begin{array}{l}\text { Fruit } \\
\text { diameter (cm) }\end{array}$ & $\begin{array}{l}\text { Fresh fruit } \\
\text { weight } \\
\text { (g) }\end{array}$ & $\begin{array}{l}\text { Juice content } \\
\text { (ml/fruit) }\end{array}$ \\
\hline$T_{1}$ : Control & 7.86 & 4.48 & 107.38 & 31.94 \\
\hline$T_{2}:$ RDF (N:P:K-100:100:100) & 8.47 & 4.86 & 120.14 & 40.26 \\
\hline$T_{3}:$ FYM $(20 \mathrm{~kg} /$ tree $)$ & 7.94 & 4.79 & 115.75 & 27.13 \\
\hline$T_{4}: \mathrm{VC}(10 \mathrm{~kg} /$ tree $)$ & 8.52 & 4.93 & 108.08 & 33.63 \\
\hline$T_{5}: \mathrm{NC}(2 \mathrm{~kg} /$ tree $)$ & 8.59 & 5.04 & 90.38 & 26.05 \\
\hline$T_{6}:$ MOC (2kg/tree) & 8.28 & 4.49 & 105.91 & 38.46 \\
\hline$T_{7}: F Y M(10 \mathrm{~kg})+\mathrm{NC}(1 \mathrm{~kg})$ & 8.28 & 4.64 & 112.50 & 43.30 \\
\hline$T_{8}:$ FYM $(10 \mathrm{~kg})+$ MOC $(1 \mathrm{~kg})$ & 7.96 & 5.02 & 94.63 & 30.10 \\
\hline $\mathrm{T}_{9}: \mathrm{VC}(5 \mathrm{~kg})+\mathrm{NC}(1 \mathrm{~kg})$ & 8.44 & 4.97 & 121.32 & 44.43 \\
\hline$T_{10}: \operatorname{VC}(5 \mathrm{~kg})+\mathrm{MOC}(1 \mathrm{~kg})$ & 8.14 & 4.51 & 111.41 & 47.46 \\
\hline$T_{11:}$ FYM $(10 \mathrm{~kg})+\mathrm{NC}(1 \mathrm{~kg})+\mathrm{MOC}(1 \mathrm{~kg})$ & 8.25 & 5.02 & 110.19 & 38.00 \\
\hline$T_{12}: \mathrm{VC}(5 \mathrm{~kg})+\mathrm{NC}(1 \mathrm{~kg})+\mathrm{MOC}(1 \mathrm{~kg})$ & 8.18 & 4.67 & 96.62 & 29.68 \\
\hline CD@5\% & 0.30 & 0.41 & 13.48 & 9.55 \\
\hline CV & 2.20 & 5.16 & 7.38 & 15.73 \\
\hline
\end{tabular}

$\mathrm{CD}=$ critical difference, $\mathrm{CV}=$ co-efficient of variance 
Table.4 Effect of organic manures on the fruit quality parameters of Assam Lemon

\begin{tabular}{|c|c|c|c|c|c|c|}
\hline Treatments & $\begin{array}{c}\text { TSS } \\
\left({ }^{\circ} \text { Brix }\right)\end{array}$ & $\begin{array}{c}\text { Total } \\
\text { Sugar }(\%)\end{array}$ & $\begin{array}{c}\text { Reducing } \\
\text { Sugar } \\
(\%)\end{array}$ & $\begin{array}{l}\text { Non-reducing } \\
\text { sugar } \\
(\%)\end{array}$ & $\begin{array}{c}\text { Titratable } \\
\text { Acidity (\%) }\end{array}$ & $\begin{array}{l}\text { Ascorbic Acid } \\
\text { (mg/100g) }\end{array}$ \\
\hline $\mathrm{T}_{1}:$ Control & 4.35 & 4.48 & 3.09 & 1.39 & 3.74 & 38.03 \\
\hline$T_{2}:$ RDF (N:P:K-100:100:100) & 5.38 & 6.36 & 3.98 & 2.38 & 3.84 & 45.73 \\
\hline$T_{3}:$ FYM (20kg/tree) & 5.56 & 5.15 & 2.51 & 2.63 & 3.50 & 44.76 \\
\hline $\mathrm{T}_{4}: \mathrm{VC}(10 \mathrm{~kg} /$ tree $)$ & 5.31 & 4.48 & 2.99 & 1.48 & 4.26 & 45.80 \\
\hline $\mathrm{T}_{5}: \mathrm{NC}(2 \mathrm{~kg} /$ tree $)$ & 5.04 & 4.84 & 2.32 & 2.52 & 4.58 & 44.96 \\
\hline $\mathrm{T}_{6}:$ MOC (2kg/tree) & 5.52 & 5.87 & 4.04 & 1.82 & 4.81 & 44.03 \\
\hline $\mathrm{T}_{7}: \mathrm{FYM}(10 \mathrm{~kg})+\mathrm{NC}(1 \mathrm{~kg})$ & 5.10 & 4.26 & 2.63 & 1.63 & 3.41 & 44.10 \\
\hline$T_{8}:$ FYM $(10 \mathrm{~kg})+$ MOC $(1 \mathrm{~kg})$ & 5.49 & 5.42 & 2.78 & 2.63 & 4.26 & 43.96 \\
\hline $\mathrm{T}_{9}: \mathrm{VC}(5 \mathrm{~kg})+\mathrm{NC}(1 \mathrm{~kg})$ & 5.67 & 5.22 & 3.52 & 1.69 & 3.29 & 51.86 \\
\hline $\mathrm{T}_{10}: \mathrm{VC}(5 \mathrm{~kg})+\mathrm{MOC}(1 \mathrm{~kg})$ & 5.78 & 6.19 & 3.62 & 2.57 & 3.38 & 52.63 \\
\hline $\mathrm{T}_{11:}$ FYM (10kg)+ NC (1kg) + MOC (1 kg) & 5.18 & 5.24 & 2.78 & 2.46 & 4.14 & 51.86 \\
\hline $\mathrm{T}_{12}: \mathrm{VC}(5 \mathrm{~kg})+\mathrm{NC}(1 \mathrm{~kg})+\mathrm{MOC}(1 \mathrm{~kg})$ & 5.23 & 6.13 & 3.72 & 2.41 & 4.58 & 50.30 \\
\hline CD@5\% & 0.39 & 0.71 & 0.92 & 0.44 & 0.44 & 6.5 \\
\hline $\mathrm{CV}$ & 4.36 & 7.93 & 17.17 & 12.33 & 6.57 & 8.3 \\
\hline
\end{tabular}

$\mathrm{CD}=$ critical difference, $\mathrm{CV}=$ co-efficient of variance 
Table.5 Effect or organic manures on physico-chemical properties of soil

\begin{tabular}{|c|c|c|c|c|c|c|}
\hline Treatments & $\mathbf{p H}$ & $\begin{array}{l}\text { Electrical } \\
\text { Conductivity } \\
(\mathrm{dS} / \mathrm{m})\end{array}$ & $\begin{array}{l}\text { Organic } \\
\text { Carbon } \\
(\%) \\
\end{array}$ & $\begin{array}{l}\text { Available } \\
\text { Nitrogen } \\
\text { (kg/ha) }\end{array}$ & $\begin{array}{l}\text { Available } \\
\mathrm{P}_{2} \mathrm{O}_{5} \\
\text { (kg/ha) }\end{array}$ & $\begin{array}{l}\text { Available } \\
\mathrm{K}_{2} \mathrm{O} \\
\text { (kg/ha) }\end{array}$ \\
\hline $\mathbf{T}_{1}:$ Control & 5.90 & 0.07 & 2.10 & 232.74 & 19.77 & 230.76 \\
\hline$T_{2}:$ RDF (N:P:K-100:100:100) & 5.76 & 0.35 & 2.61 & 321.48 & 32.85 & 260.00 \\
\hline$T_{3}:$ FYM (20kg/tree) & 5.80 & 0.08 & 2.00 & 310.48 & 33.97 & 251.60 \\
\hline$T_{4}:$ VC (10kg/tree) & 5.73 & 0.15 & 2.32 & 329.24 & 42.67 & 270.40 \\
\hline$T_{5}:$ NC (2kg/tree) & 5.66 & 0.06 & 2.35 & 339.96 & 33.22 & 263.30 \\
\hline $\mathrm{T}_{6}:$ MOC (2kg/tree) & 5.83 & 0.18 & 2.08 & 363.74 & 50.02 & 298.92 \\
\hline $\mathrm{T}_{7}: \mathrm{FYM}(10 \mathrm{~kg})+\mathrm{NC}(1 \mathrm{~kg})$ & 5.93 & 0.06 & 2.05 & 347.05 & 39.20 & 275.06 \\
\hline$T_{8}:$ FYM (10kg)+ MOC (1kg) & 6.13 & 0.54 & 2.41 & 387.95 & 42.76 & 247.10 \\
\hline $\mathrm{T}_{9}: \mathrm{VC}(5 \mathrm{~kg})+\mathrm{NC}(1 \mathrm{~kg})$ & 6.13 & 0.24 & 2.31 & 380.50 & 42.18 & 265.20 \\
\hline$T_{10}: \operatorname{VC}(5 \mathrm{~kg})+\operatorname{MOC}(1 \mathrm{~kg})$ & 5.86 & 0.17 & 2.31 & 430.52 & 57.30 & 306.13 \\
\hline $\mathrm{T}_{11:}$ FYM (10kg)+ NC (1kg) + MOC (1kg) & 6.16 & 0.23 & 2.62 & 410.49 & 40.69 & 300.78 \\
\hline$T_{12}: \mathrm{VC}(5 \mathrm{~kg})+\mathrm{NC}(1 \mathrm{~kg})+\mathrm{MOC}(1 \mathrm{~kg})$ & 5.86 & 0.07 & 2.50 & 413.82 & 53.93 & 305.93 \\
\hline CD@ $9 \%$ & 0.30 & 0.22 & 0.22 & 34.03 & 12.20 & 17.88 \\
\hline CV & 3.05 & 71.63 & 5.64 & 5.65 & 17.69 & 3.87 \\
\hline
\end{tabular}

$\mathrm{CD}=$ critical difference, $\mathrm{CV}=$ co-efficient of variance 
Table.6 Effect of organic manures on the leaf NPK status of Assam lemon

\begin{tabular}{|c|c|c|c|}
\hline Treatments & $\begin{array}{l}\text { Total Nitrogen } \\
(\%)\end{array}$ & $\begin{array}{l}\text { Total Phosphorus } \\
(\%)\end{array}$ & $\begin{array}{l}\text { Total Potassium } \\
(\%)\end{array}$ \\
\hline$T_{1}$ : Control & 1.51 & 0.12 & 1.32 \\
\hline$T_{2}:$ RDF (N:P:K-100:100:100) & 2.20 & 0.15 & 1.66 \\
\hline$T_{3}:$ FYM $(20 \mathrm{~kg} /$ tree $)$ & 1.90 & 0.15 & 1.42 \\
\hline$T_{4}: \mathrm{VC}(10 \mathrm{~kg} /$ tree $)$ & 1.95 & 0.14 & 1.42 \\
\hline$T_{5}: \mathrm{NC}(2 \mathrm{~kg} /$ tree $)$ & 1.84 & 0.14 & 1.55 \\
\hline$T_{6}:$ MOC $(2 \mathrm{~kg} /$ tree $)$ & 2.25 & 0.15 & 1.56 \\
\hline$T_{7}: F Y M(10 k g)+N C(1 \mathrm{~kg})$ & 2.11 & 0.14 & 1.41 \\
\hline$T_{8}:$ FYM(10kg)+MOC $(1 \mathrm{~kg})$ & 2.02 & 0.15 & 1.39 \\
\hline$T_{9}: \operatorname{VC}(5 \mathrm{~kg})+\mathrm{NC}(1 \mathrm{~kg})$ & 2.13 & 0.14 & 1.43 \\
\hline$T_{10}: \operatorname{VC}(5 \mathrm{~kg})+\operatorname{MOC}(1 \mathrm{~kg})$ & 2.35 & 0.16 & 1.66 \\
\hline $\begin{array}{l}\text { T}_{11:} \text { FYM }(10 \mathrm{~kg})+\mathrm{NC}(1 \mathrm{~kg})+ \\
\text { MOC }(1 \mathrm{~kg})\end{array}$ & 2.09 & 0.13 & 1.62 \\
\hline $\begin{array}{l}T_{12}: \mathrm{VC}(5 \mathrm{~kg})+\mathrm{NC}(1 \mathrm{~kg})+\mathrm{MOC} \\
(1 \mathrm{~kg})\end{array}$ & 2.23 & 0.15 & 1.67 \\
\hline CD@ $@ 5 \%$ & 0.28 & 0.01 & 0.21 \\
\hline CV & 8.26 & 7.03 & 8.38 \\
\hline
\end{tabular}

$\mathrm{CD}=$ critical difference, $\mathrm{CV}=$ co-efficient of variance

There was significant improvement in all of the quality characteristics of the fruit. Previous works of Garhwal et al., (2014) in Kinnow mandarin, Ghosh et al., (2014) in sweet orange and Kumar et al., (2018) in mango have reported improvement in fruit quality due to incorporation of organic manures.

\section{Soil and Leaf Parameters}

Perusal of the data showed that most of the soil and leaf parameters gave significantly relevant differences due to the effect of the application of organic manures. However, it was revealed that the different treatments had no significant effect on the $\mathrm{pH}$ and electrical conductivity of the soil.

The highest available nitrogen, phosphorus, potassium, organic carbon content of the soil and total nitrogen, phosphorus and potassium content of the leaves were recorded in $\mathrm{T}_{10}$ (Vermicompost @ 5kg + Mustard Oil Cake@
$1 \mathrm{~kg}$ ). The results of the the present findings is in accordance with Ghosh et al., (2014), who reported that incorporation of vermicompost and mustard oil cake resulted in highest available $\mathrm{N}$ and $\mathrm{P}$ content of soil and leaf. It is also in concordance with Makode (2015) who reported that basal application of $10 \mathrm{~kg}$ vermicompost per plant resulted in significant improvement of the porosity and drainage and nutrient content of soils and water conservation. Vermicompost betters the porosity and drainage, nutrient content of soil and conservation of water which subsequently results in easy uptake of water as well as deposition of nutrients.

The application of various organic sources caused a significant increase in organic carbon content of the soils after harvest in contrast to the initial soil status. The slow releasing nature of organic manures makes consistent availability of nutrients throughout the growth period. Similar outcome was found by 
Hazarika and Aheibam (2019) in Assam lemon. This may be attributed to increased microbial population and activity, stabilization of the $\mathrm{C}: \mathrm{N}$ ratio, addition of organic matter into the soil through the organic manures. The increased nitrogen content may be due to the increase in the population of micro-organisms that converts the inaccessible form of nitrogen to readily available form.

\section{References}

A.O.A.C. (2002). Official methods of analysis. Association of Official Analytical Chemists International, Washington D.C. pp. 1-12.

Barua, B.C. and Bharadwaj, S. (2017). Assam lemon-a prospective NPD initiative aimed at global market positioning.

Bray, R.H. and Kurtz, L.P. (1945). Determination of total organic and available form of phosphorus in soil. Soil sci., 59: 39-45.

Garhwal, P.C., Yadav, P.K., Sharma, B.D., Singh, R.S. and Ramniw A.S. (2014). Effect of organic manure and nitrogen on growth, yield and quality of Kinnow Mandarin in sandy soils of hot arid region. Afr. J. Agric. Res., 9(34):2638-2647.

Ghosh, A., Dey, K., Bhowmick, N., Ghosh, S.K., Bandyopadhyay, S., Medda, P.S. and Ghosh, A. (2017). Lemon cv. Assam lemon (Citrus limon Burm.) quality and soil-leaf nutrient availability affected by different pruning intensities and nutrient management. Curr. Sci., 112(10):20512065.

Gomez, A.K. and Gomez, A.A. (2010). Statistical procedures for agricultural research. $2^{\text {nd }}$ edn. Wiley India Private Limited, New Delhi, pp. 134-138.

Hanway, J.J. and Heidel, H. (1952). Soil analysis methods used in Iowa state soil testing laboratory, Iowa Agric.,
57:1-31.

Hazarika, T.K. and Aheibam, B. (2019). Soil nutrient status, yield and quality of lemon (Citrus limon Burm.) cv. 'Assam lemon' as influenced by biofertilizers, organics and inorganic fertilizers. J. Plant Nutri., 42(3):1-11.

Heitkamp, F., Raupp, J. and Ludwig, B. (2009). Impact of fertilizer type and rate on carbon and nitrogen pools in a sandy Cambisol. Plant Soil, 319:288293.

Hodge, J.E. and Hofreiter, B.T. (1962). Determination of reducing sugars and carbohydrates, In: Whistler, R.L. and Wolfrom, M.L. (eds) Methods in carbohydrate chemistry, $17^{\text {th }}$ edn. Academic Press, New York.

Kumar, M., Rajkumar, Singh, R. and Kumar, L. (2018). Effect of organic manures on physical and chemical characteristics of mango cv. Dashehari at ambient storage conditions. Int.J.Curr.Microbiol.App.Sci., $\quad 7(01)$ : 31-39.

Makode, P.M. (2015). Effect of vermicompost on the growth of Indian orange, Citrus reticulatus with reference to its quality and quantity. Biosci. Biotech. Res. Comm., 8(2): 217-220.

Morgan, K.T. (2009). Response of young and maturing citrus trees grown on a sandy soil to irrigation scheduling, nitrogen fertilizer rate, and nitrogen application method. HortScience., 44:145-150.

Perungkotturselvi, C. and Koilraj, A.J. (2015). Organic farming Acid lime plant fruits Citrus aurantifolia at Puliangudi in Nellai district, Tamil Nadu State, India. Int. J. Curr. Microbiol. App. Sci., 4(9): 576-581.

Ranganna, S. (1986).Handbook of Analysis and Quality Control for Fruit and Vegetable Products. Tata McGraw Hill Publishing Co. Ltd., New Delhi, pp.190-210. 
Sangeeta B.H., Patil, D.R., Gandolkar, K., Raghavendra K. M., Nagaraj, M.S., Nadaf, A.M. and Prakash, D.P. (2017). Response of pomegranate to different organic manures under Northern dry zone of Karnataka, India. Int. J. Curr. Microbiol. App. Sci., 6(11): 86-90.

Somogyi, N. (1952). Estimation of sugars by calorimetric method. J. Biol. Chem., 200: 245.

Subbaiah, B. V. and Asija, G. L. (1956). A rapid procedure for the estimation of available nitrogen in soil. Curr. Sci.,
25: 259-260.

Uddin, M.R., Hossain, M.F., S M Zaman, S.M., Islam, M. and Ara, N. (2014). Effect of organic manure on growth and yield of strawberry. Wudpecker $J$. Agric. Res., 3(1):35 -38.

Walkley, A. and Black, I. A.. 1934. An examination of Degtjareff method for determining soil organic matter and a proposed modification of the chromic acid titration method. Soil Sci., 37: 2937.

\section{How to cite this article:}

Rosangpuii Pachuau, Barun Singh, Jes Lalnunpuia and Lalthamawii 2019. Effect of Organic Manures on Growth, Yield and Quality of Assam Lemon [Citrus limon (L.) Burm.]. Int.J.Curr.Microbiol.App.Sci. 8(09): 1009-1019. doi: https://doi.org/10.20546/ijcmas.2019.809.118 